\title{
DURATION OF INTRADERMAL ANAESTHESIA WITH MIXTURES OF BUPIVACAINE AND LIDOCAINE
}

\author{
P.T. Sweet, D.A. Magee and A.J.C. Holland
}

\begin{abstract}
In a double-blind trial on 20 human volunteers, the duration of intradermal anaesthesia with bupivacaine 0.25 per cent was compared with duration with a mixture of bupivacaine 0.25 per cent and carbonated lidocaine 1.0 per cent and with a mixture of bupivacaine 0.25 per cent and lidocaine hydrochloride 1.0 per cent.

The duration of intradermal anaesthesia produced by bupivacaine mixed with carbonated lidocaine was $114 \pm 56$ (mean \pm I SD) minutes and was not significantly shorter than the duration of the bupivacaine alone, at $125 \pm 70$ minutes, or duration with the mixture of bupivacaine and lidocaine hydrochloride, which was $112 \pm 41$ minutes.

These results indicate that the mixture of bupivacaine with either carbonated lidocaine or lidocaine hydrochloride may be used for local anaesthesia without significant shortening of the duration of action.
\end{abstract}

KEY WORDS: ANAESTHETICS, LOCAL, bupivacaine, lidocaine.

LOCAL ANAESTHETICS are often compounded to obtain the benefit of the rapid action of one agent and the longer duration of another. However, it has been shown that the mixing of some local anaesthetics can result in an interaction with consequent shortening of the duration of action. ${ }^{\text {' }}$

The mixing of bupivacaine and carbonated lidocaine has been recommended by Bromage and Gertel for use in brachial plexus blocks ${ }^{2}$ and our clinical impression has been that with this mixture the duration of action of the bupivacaine is not markedly reduced. We therefore decided to carry out a trial to establish if this impression was true, and also to determine whether the mixture of bupivacaine with lidocaine hydrochloride was equally long lasting.

\section{METHODS}

A double-blind study was done on 20 healthy young volunteers. Informed consent was obtained from each individual.

Intradermal wheals were raised on the volar aspect of the forearm with $0.2 \mathrm{ml}$ of three local anaesthetic solutions. One solution was bupi-

P.T. Sweet, M.B., B.S., (Lond.) F.F.A.R.C.S., Clinical Fellow; D.A. Magee, M.B., B.Ch., F.F.A.R.C.S.I., Clinical Fellow; A.J.C. Holland, M.B., B.S., F.F.A.R.C.S., D.C.H., Associate Professor Department of Anaesthesia, McGill University, The Montreal General Hospital, 1650 Cedar Avenue, Montreal, P.Q., H3G 1 A4. vacaine 0.25 per cent, made by diluting bupivacaine 0.5 per cent with an equal volume of normal saline. A second solution was a mixture of equal volumes of bupivacaine 0.5 per cent and lidocaine hydrochloride 2 per cent, equivalent to bupivacaine 0.25 per cent and lidocaine hydrochloride 1.0 per cent. The third solution was a mixture of equal volumes of bupivacaine 0.5 per cent and carbonated lidocaine 2.0 per cent to give a final equivalent of bupivacaine 0.25 per cent and carbonated lidocaine 1.0 per cent.

Following the injections analgesia to pinprick on the injection site was determined every five minutes until full sensation returned. The duration of action was measured from the time of injection to the last reported analgesia. Statistical analysis was done using the Student $t$ test.

\section{RESULTS}

The onset of intradermal analgesia was similar with all three solutions, and was uniformly present when tested at five minutes. The mean duration of intradermal analgesia with bupivacaine 0.25 per cent was $125 \pm 70$ minutes (mean \pm 1 standard deviation), with the mixture of bupivacaine and carbonated lidocaine $114 \pm 56$ minutes and with bupivacaine and lidocaine hydrochloride $112 \pm 41$ minutes. The difference between mean duration of action of bupivacaine

Can. Anaesth. Soc. J., vol. 29, no. 5, September 1982 
TABLE I

DURATION OF ACTION OBTAINED BY BUPIVACAINE ALONE, MIXTURE OF BUPIVACAINE AND CARBONATED LIDOCAINE AND A MIXTURE OF BUPIVACAINE AND LIDOCAINE HYDROCHLORIDE

\begin{tabular}{|c|c|}
\hline Local Anaesthetic & $\begin{array}{l}\text { Duration in minutes } \\
\text { (mean } \pm 1 \mathrm{SD} \text { ) }\end{array}$ \\
\hline $\begin{array}{l}\text { Bupivacaine } \\
0.25 \text { per cent }\end{array}$ & $125 \pm 70$ \\
\hline $\begin{array}{l}\text { Bupivacaine } \\
0.25 \text { per cent }\end{array}$ & \\
\hline $\begin{array}{l}\text { and } \\
\mathrm{CO}_{2} \text { lidocaine } \\
1 \text { per cent }\end{array}$ & $114 \pm 56$ \\
\hline $\begin{array}{l}\text { Bupivacaine } \\
0.25 \text { per cent }\end{array}$ & \\
\hline $\begin{array}{l}\text { and } \\
\text { lidocaine } \mathrm{HCl} \\
1 \text { per cent }\end{array}$ & $112 \pm 41$ \\
\hline
\end{tabular}

and the mixture of bupivacaine and carbonated lidocaine was 11 minutes, and the difference between bupivacaine and the mixture of bupivacaine and lidocaine hydrochloride was 13 minutes. The difference between the two mixtures was two minutes (Table I). Statistical analysis showed that these differences were not significant.

\section{Discussion}

The advantage of a long duration of action of bupivacaine is offset by its long latent period. One approach to dealing with this problem has been to use carbonated bupivacaine, ${ }^{3,4}$ but whether this decreases the latent period has yet to be proven. ${ }^{5}$ Another approach has been to use mixtures of bupivacaine with other local anaesthetics having a shorter latent period. This approach assumes that the two agents do not interact and that each behaves as if the other agent is not present. For instance Kim, Goto and Arakewa ${ }^{1}$ have shown that when chloroprocaine is mixed with bupivacaine, the resultant mixture has a duration of action only slightly longer than that of chloroprocaine alone and significantly shorter than bupivacaine.

It has been suggested that the reduction in duration of action seen with the chloroprocaine and bupivacaine mixture is due to several factors, including differences between the $\mathrm{pH}$ and pKa of the two agents ${ }^{6}$ and also, perhaps, due to competitive binding to non-specific receptor sites in the tissues. ' The $\mathrm{pH}$ and $\mathrm{pKa}$ of bupivacaine and lidocaine are similar ${ }^{6}$ and they may therefore be less likely to interfere with one another.

Bromage and Gertel ${ }^{2}$ have suggested that a mixture of bupivacaine and carbonated lidocaine is ideal for use in brachial plexus block. In their study the mean duration of action of bupivacaine 0.25 per cent with epinephrine was 630 minutes and the mean duration of action of the mixture of carbonated lidocaine 1.0 per cent and bupivacaine 0.25 per cent with epinephrine was 453 minutes, but their study was neither randomized nor conducted double-blind and no comment was made on the statistical significance of this difference. Kaukinen, Kaukinen and Eerola ${ }^{8}$ have studied the mixture of bupivacaine and lidocaine in epidural blocks and concluded that the mixture of bupivacaine and lidocaine had a duration of action equivalent to that of bupivacaine alone, but that it produced less motor block; this can probably be explained by the fact that the concentration of the bupivacaine in their mixture was 0.375 per cent and their control concentration of bupivacaine was 0.5 per cent.

The clinical impression that mixtures of bupivacaine and lidocaine work well has been corroborated in this study, which has not demonstrated a statistical difference between the duration of action of bupivacaine and its mixture with either carbonated lidocaine or lidocaine hydrochloride when used for intradermal anaesthesia. Whether this is true when the mixture is used for epidural or other nerve blocks has yet to be elucidated.

\section{REFERENCES}

1. Kim, J.M., Goto, H. \& ARaKaWA, K. Duration of bupivacaine intradermal anaesthesia when the bupivacaine is mixed with chloroprocaine. Anaesth. and Analg. 58(5): 364 (1979).

2. Bromage, P.R. \& Gertel, $M$. Improved brachial plexus blockade with bupivacaine hydrochloride and carbonated lidocaine. Anaesthesiology. 36: 479 (1972).

3. ECKSTEIN, K.L., VICENTE-ECKSTEIN, A., STEINER, R. \& MISSLER, V. Klinische erprobung von bupivacaine $\mathrm{CO}_{2}$. Anaesthetist. 27: 1 (1978).

4. MCCluRE, J.H. \& SCOTT, D.B. Comparison of bupivacaine hydrochloride and carbonated bupivacaine in brachial plexus block by the inter scalene technique. Brit. J. Anaesth. 53: 523 (1981).

5. Brown, D.T., Morrison, D.H., Covino, B.G. \& SCOTT, D.B. Comparison of carbonated bupivacaine and bupivacaine hydrochloride for extradural anaesthesia. Brit. J. Anaesth. 52: 419 (1980). 
6. Brodsky, J.B. \& Brock-UtNe, J.G. Mixing Local Anaesthetics. Brit. J. Anaesth. 50: 1269 (1978).

7. LUDENA, F.P. Duration of local anaesthesia. Annu. Rev. Pharmacol. 9: 503 (1969).
8. Kaukinen, S., Kaukinen, L. \& Eerola, R. Epidural anaesthesia with mixtures of bupivacaine-lidocaine and etidocaine-lidocaine. Ann. Chir. Gynaecol. 69(6): 281 (1980).

\section{RÉSUMÉ}

$\mathrm{Au}$ cours d'une étude à double insu réalisée sur 20 volontaires, la durée d'action de l'anesthésie intradermique de la bupivacaïne 0.25 pour cent a été comparée avec elle d'un mélange de bupivacaïne 0.25 pour cent et lidocaine carbonatée 1.0 pour cent ou d'un mélange de bupivacaïne 0.25 pour cent et lidocaine 0.1 pour cent ordinaire. La durée de l'anesthésie produite par le mélange bupivacaïne et de lidocaïne carbonatée, $114 \pm 56$ (moyenne \pm 1 E.T.) minutes, n'a pas été plus courte de façon significative que celle produite par la bupivacaïne seule, $125 \pm 70$ minutes, ou le mélange de bupivacaine et de lidocaïne ordinaire, $112 \pm 41$ minutes.

Ces résultats montrent que le mélange bupivacaïne-lidocaïne, carbonatée ou ordinaire peut être utilisée pour produire l'anesthésie locale sans diminution significative de la durée d'action de la bupivacaïne. 